\title{
Efficacy of Some Insecticide on Citrus Red-scale Aonidiella aurantii (Maskell) (Hemiptera:Diaspidiae) Infested Orange Trees at El-Beheira Governorate, Egypt
}

\author{
Abdel-Fattah, Rasha S. \\ Plant Protection Institute, ARC, Sabahia, Alexandria, Egypt
}

\begin{abstract}
Citrus red-scale, Aonidiella aurantii (Maskell) (Hemiptera: Diaspididae) is an armored scale infested orange trees at Kafr-Eldwar, El-Beheira Governorate. It was subjected to be controlled. Two experiments were performed to test five summer mineral oils (Super Masrona oil ${ }^{\circledR} 95 \%$, Diver oil ${ }^{\circledR} 97 \%$, Tiger oil ${ }^{\Theta} 97 \%, \mathrm{Kz}$ oil $^{\Theta}$ 95\% and CAPL2 oil $\left.{ }^{\circledR} 96.62 \%\right)$ and neonicotinoid systemic imidacloprid insecticide (Admire ${ }^{\circledR} 20 \%$ SC)against $A$. aurantii in a private orchard of orange trees (pre-flowering stage in early spring (2010) and during fruiting stages in early summer (2011)). Results indicated ascending increasable reduction effect with time intervals up to two months against $A$. aurantii. It was observed that reduction effect caused by mineral oils had increased as purification percentages increase. It could be recommended that, light summer oils gave successful control against armored red-scale insect which infest orange trees, where they were more effective and less environmental hazards than the other tested insecticide $\left(\right.$ Admire $\left.^{\circledR}\right)$.
\end{abstract}

Keywords: Citrus red scale, orange trees, summer mineral oils, neonicotinoid systemic imidacloprid insecticide

\section{INTRODUCTION}

Citrus red-scales, insect Aonidiella aurantii (Maskell) generally causes yellow chlorotic spots when attacking leaves. Yellow spots may also appear at the feeding sites on fruit. This insect appears to prefer fruit over leaves in the summer and fall; therefore, the fruit may be heavily infested, while the adjacent leaves are relatively free from them. Unlike other armored scales on citrus, the insect restrict feeding on foliage and fruit but do not attack twigs or limbs of citrus trees. Large populations of this scale insect may result in severe defoliation and fruit production would be decreased. The insect presents on the fruit will render it as unmarketable fresh fruit because it does not agree with the consumer desire. Heavily infested fruit may be downgraded in the packinghouse and, if population levels are high, serious damage can occur to trees. Severe infestations cause leaf yellowing and drop, dieback of twigs, limbs, and occasionally death of the tree. Tree damage is most likely to occur in late summer and early fall when its population is high and moisture stress on the tree is sever (Kennett et al., 1999)

Egyptian citrus considered one of the popular and cheap fruits. Citrus trees are subjected to varieties of insect pests, as the armourd scale insects, mainly the red scale insect, A.aurantii (Habib et al., 1971, Darwish, 1970 and Farag et al., 1989).Orange has become the most commonly grown fruit tree in the world. Large quantities of fresh oranges and orange juice concentrate are exported to the United States and small shipments go to East Germany, Canada and Argentina. However, overproduction has glutted domestic markets and brought down prices and returns to the farmer to such an extent that plantings have declined (Florida Citrus Pest Management Guide, 2007). Because of the damage caused by this insect to citrus trees, different control 
methods had been adopted by many investigators to prevent serious losses to the citrus crops in Egypt.

Local sprays of mineral oils are used for many years against scale insects, mealy bugs, thrips, aphids and mites on different crops and fruit trees, (El-Deeb et al., 2002 and Moursi, 1996). These oils were most commonly used in horticulture to control scale insects and mites (Chapman et al., 1952). Micks and Berlin (1970) and El Sebae et al., (1976) stated that resistance was not recorded for mineral oils which still have the advantage of being effective against the insect resistant strains.

Present study was carried out to evaluate some insecticides against citrus red-scale, [Aonidiella aurantii (Maskell)] and find out the most effective one, which could control infested orange trees successfully and synchronizely by the same application in an attempt to reduce its serious damage on citrus fruits.

\section{MATERIALS AND METHODS}

Two field experiments were carried out (during pre-flowering stage in early spring (2010) and during fruiting stages in early summer (2011)), in an orchard of orange trees at Kafr-Eldwar, El-Beheira Governorate, to evaluate the efficacy of certain compounds[five emulsifiable concentrate light summer mineral oils differ in its purification percentages (Super Masrona oil ${ }^{\oplus} 95 \%$; Diver oil $^{\circledR} 97 \%$; Tiger oil ${ }^{\circledR} 97 \% ; \mathrm{Kz}_{\mathrm{oil}}{ }^{\circledR} 95 \%$ and CAPL2 $\mathrm{oil}^{\circledR}$ 96.62\%) and Imidacloprid insecticide (Admire ${ }^{\circledR} 20 \%$ as soluble concentrate formulation)]against the armored scale insect[citrus red-scale, Aonidiella aurantii (Maskell) (Hemiptera: Diaspididae).Orange trees were 15 years old and have similar uniformity in height, shape and sizeand highly infested with citrus red-scale insect.

Experiments were designed as a complete randomized block design. Spraying was accomplished by means of a conventional knapsack sprayer with a capacity of 20 liters/tank; at rate of 10-12 liters per tree to ensure complete coverage of all parts of the tree. Six treatments as well as the untreated check were replicated four times with six trees per replicate and randomly distributed over 168 trees. Random samples of thirty leaves from each replicate were selected for laboratory counts $(0,2,4,6$ and 8 weeks) before and after spraying. Samples were put in labeled cloth bags and transferred to the laboratory for counting using the stereoscopic binocular microscope.The reduction of the inspection of both insects numbers was expressed as reduction percentages which were calculated according to Henderson and Tilton (1955). Statistical analysis of variance and LSD value for comparing the mean effects of each treatment were adopted according to Snedecor (1961).The tested compounds are shown in Table (1) . 
Table 1: the used insecticides in the evaluation

\begin{tabular}{|c|c|c|}
\hline Compounds & Rate\% & Source (Company) \\
\hline Super Masrona oil ${ }^{\circledR}$ 95\%, E.C & 1.5 & Misr Petrolium Co. \\
\hline $\begin{array}{l}\text { Diver oil }{ }^{\circledR} 97 \% \text {, E.C } \\
\text { Tiger oil }^{\circledR} 97 \%\end{array}$ & $\begin{array}{l}1.5 \\
15\end{array}$ & El-Helb pesticides and Chemical Co. \\
\hline Kz oil ${ }^{\circledR} 95 \%$ E.C & 1.5 & Kafr El-Ziat Pesticides and Chemicals Cc \\
\hline CAPL2 oil ${ }^{\circledR} 96.62 \%$, E.C & 1.5 & Central Agriculture Pesticides Laboratory (CAPL) \\
\hline Admire $^{\circledR} 20 \%$ SC, (Imidacloprid) & $1 \%$ & Shenzhen Cropstar Chemical Industry Co., Ltd. \\
\hline
\end{tabular}

\section{RESULTS AND DISCUSSION}

All tested treatments showed ascending increasable effect with time intervals against the tested insect during the two experiments periods. It was observed that the reduction of the tested insect populations caused by Mineral oils increased directly proportional with their purification percentages.

\section{A) Effect of tested compounds during pre-flowering stage}

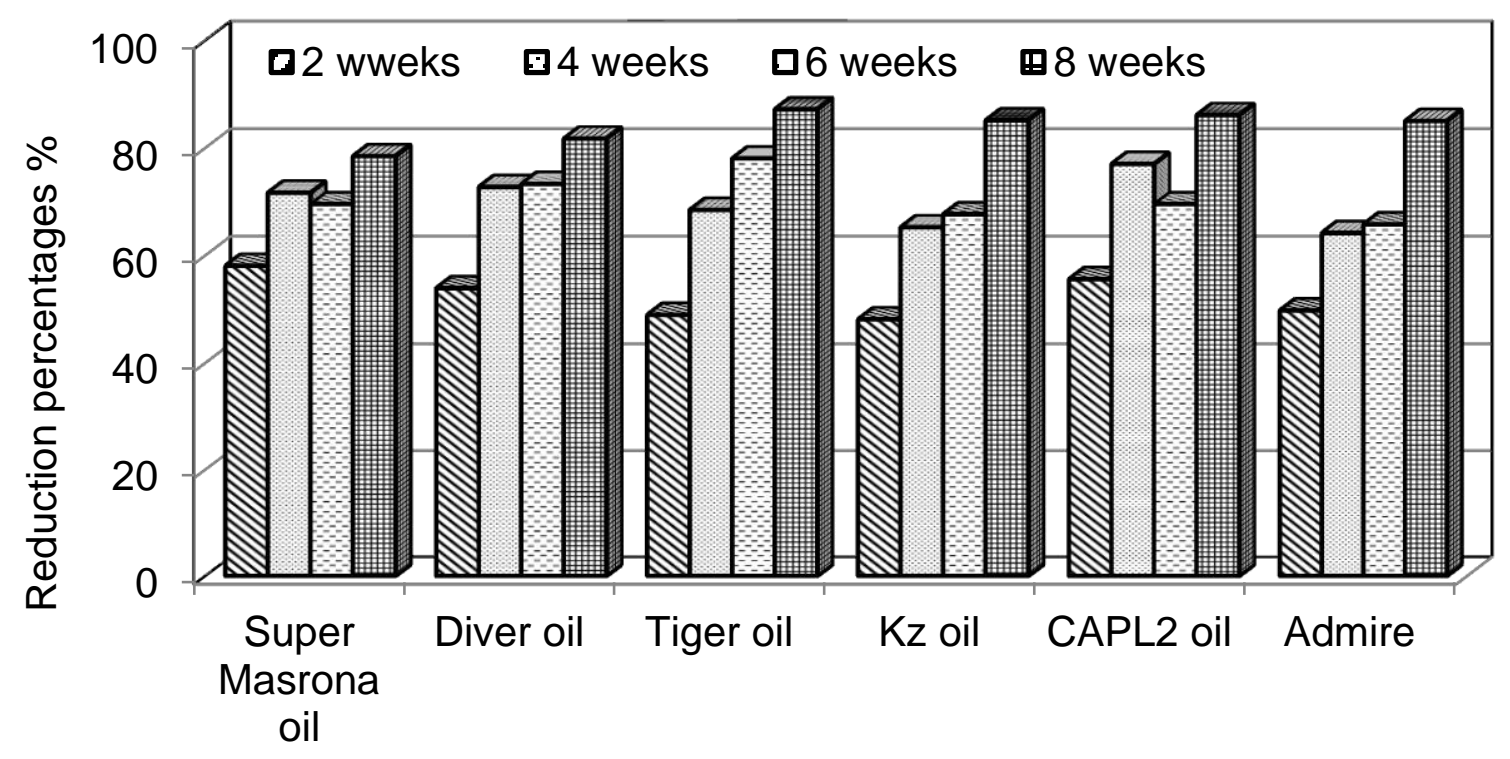

Treatments

L.S. $D_{0.05}$ (Means) $=1.59$

Figure1: Efficacy of tested insecticides against the citrus red-scale insect Aonidiella aurantii (Maskell) infested orange trees, at Kafr-Eldwar, El-Beheira Governorate, during pre-flowering stage (2010).

Data in Fig. (1) illustrate the effect of the tested compounds against the citrus red-scale Aonidiella aurantii (Maskell) insect (Hemiptera: Diaspididae) during pre-flowering stage. Data show that reduction percentages increased by increasing the time after treatment, where the highest reduction percentages for all tested chemicals appeared after eight weeks, while after two weeks they caused the least reduction percentages.

After two weeks from treatments of test chemicals Super Masrona oi ${ }^{\circledR}$ was the most effective one, where it caused reduction percentage (58.2\%) 
followed by CAPL2 ${ }^{\circledR}$ oil $(56.1 \%)$ without significant differences; but they differ significantly with Diver oil ${ }^{\circledR}(54.3 \%)$; and so withAdmire ${ }^{\circledR}(50.4 \%)$; Tiger oil ${ }^{\Theta}$ $(49.2 \%)$ and $\mathrm{Kzoil}^{\circledR}(48.0 \%)$ which have not significant differences in between. After four weeks CAPL2 oil ${ }^{\circledR}$ was the most effective treatment where it caused reduction percentage $(77.2 \%)$ with significant differences with the two next effective treatments Diver oil ${ }^{\circledR}(73.0 \%)$ and Super Masrona oil ${ }^{\circledR}(72.3 \%)$. Tiger $\mathrm{oil}^{\circledR}$ caused (68.2\%) reduction effect differing significantly with the previous and followed treatments. $\mathrm{Kz}$ oil ${ }^{\circledR}$ caused reduction percentage $(65.5 \%)$ without significant differences with Admire ${ }^{\circledR}$ (64.4\%). After six weeks of application Tiger $\mathrm{oil}^{\circledR}$ was the most effective treatment followed by Diver oil ${ }^{\circledR}$, Super Masrona oil ${ }^{\circledR}$, CAPL2 oil $^{\Theta}, \mathrm{Kz}$ oil ${ }^{\Theta}$ and Admire ${ }^{\circledR}$ where they caused reduction effects as (78.1\%), (73.2\%), (70.6\%), (70.0\%), (68.0\%) and (66.3\%), respectively. Data Means showed that CAPL2 oil $^{\circledR}$ was the most effective compound through the experiment where it caused average mean reduction effect $(72.9 \%)$ followed by Tiger oil ${ }^{\Theta}(71.3 \%)$ and Diver oil ${ }^{\Theta}(70.4 \%)$ without significant differences in between. Super Masrona oil ${ }^{\circledR}$ caused reduction effect $(69.2 \%)$ with significant differences with $\mathrm{Kz}$ oil $^{\circledR}(67.4 \%)$ and Admire insecticide caused mean reduction effect value (66.6\%) without significant differences with $\mathrm{Kz}$ oil ${ }^{\circledR}$.

\section{B) Effect of tested compounds during fruiting stage}

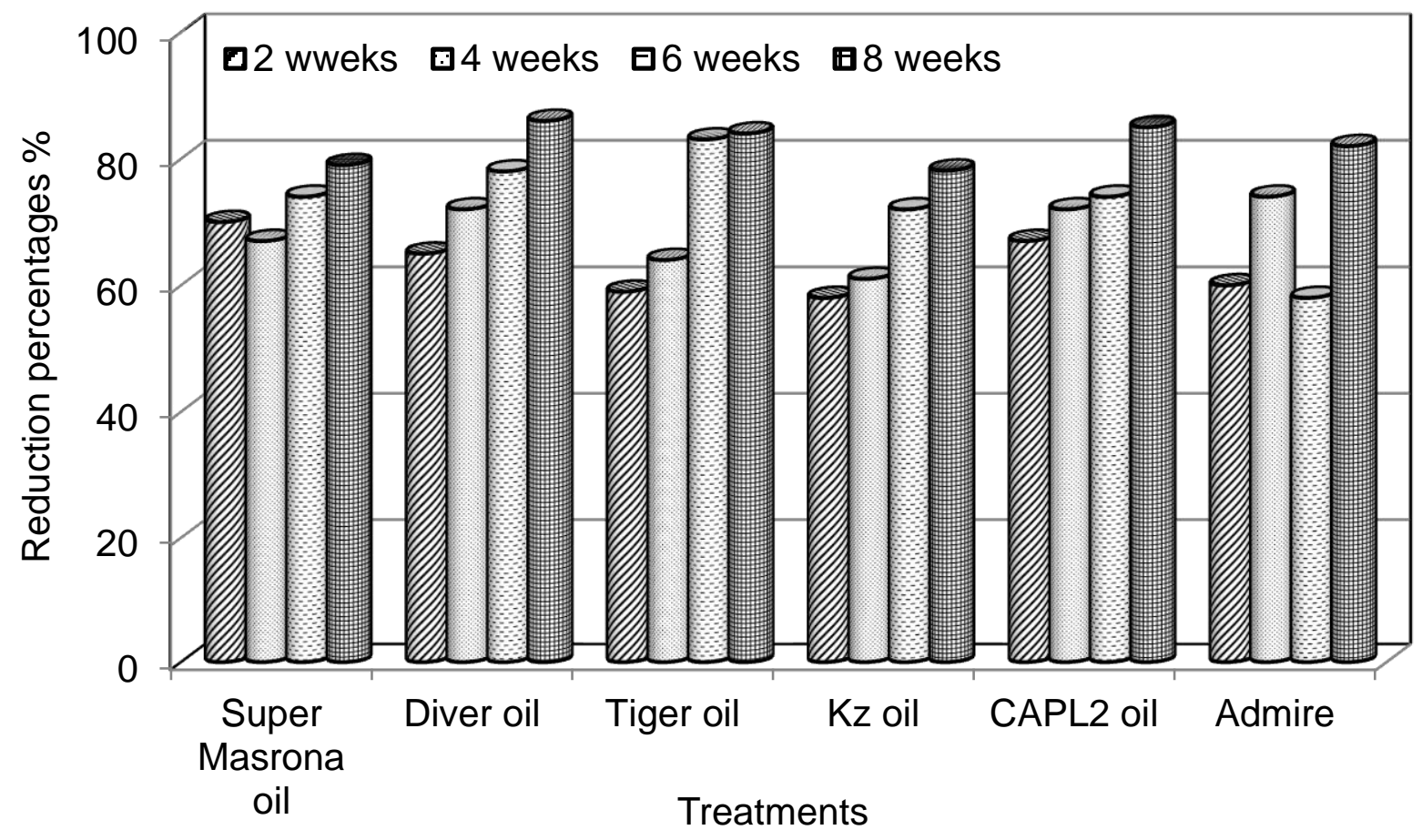

L.S. $D_{0.05}$ (Means) $=1.41$

Figure 2 : Efficacy of some insecticide; against the citrus red-scale insect Aonidiella aurantii (Maskell) infest orange trees, at Kafr-Eldwar, El-Beheira Governorate, during fruiting stage (2011).

Data in Fig. (2) illustrate the effect of the tested compounds against the citrus red-scale Aonidiella aurantii (Maskell) insect during fruiting stage. Diver $\mathrm{oil}^{\circledR} 97 \%$ caused the highest reduction effect influence against the tested insect and $\mathrm{Kz}$ oil ${ }^{\circledR} 95 \%$ was the least effective one. Two weeks after treatment Super 
Masrona oil ${ }^{\circledR}$ gave the highest reduction effect $(70 \%)$ followed by CAPL2 oil ${ }^{\circledR}$ $(67.1 \%)$ and Diver oil ${ }^{\Theta}(65.2 \%)$ without significant differences, but they significantly differed with Admire ${ }^{\circledR}(60 \%)$, Tiger oil ${ }^{\circledR}(59.6 \%)$ and $\mathrm{Kz}$ oil ${ }^{\circledR}(58.1 \%)$. After four weeks, Admire ${ }^{\circledR}$ caused the highest reduction effect $(74.3 \%)$ without significant differences with CAPL2 oil ${ }^{\circledR}(72.6)$ and Diver oil ${ }^{\circledR}(72.1 \%)$, and significantly differed with Super Masrona oil ${ }^{\circledR}(67.2 \%)$, Tiger oil ${ }^{\circledR}(64.3 \%)$ and $\mathrm{Kz}$ $\mathrm{oil}^{\Theta}(61 \%)$. After six weeks of application Tiger oil ${ }^{\circledR}$ was the most effective treatment followed by Diver oil ${ }^{\circledR}$, Super Masrona oi ${ }^{\circledR}, \mathrm{CAPL} 2 \mathrm{oil}^{\circledR}, \mathrm{Kz} \mathrm{oil}^{\circledR}$ and Admire ${ }^{\circledR}$ where they caused reduction effects as $83 \%, 78.2 \%, 74.6 \%, 74.3 \%$, $72.0 \%$ and $58.4 \%$ respectively. Diver oil ${ }^{\Theta}$ was the most effective treatment after eight weeks from application where it caused reduction effect $(86 \%)$, followed by CAPL2 oil ${ }^{\circledR}(85.4 \%)$, Tiger oil ${ }^{\Theta}(84.2 \%)$ and Admire ${ }^{\circledR}(82.0 \%)$ without significant differences between them while they significantly differed with Super Masrona oil ${ }^{\circledR}(79.1 \%)$ and $\mathrm{Kz}$ oil $^{\circledR}(77.9 \%)$.

Means of data showed that Diveroil ${ }^{\circledR}$ was the most effective compound through the experiment where it caused average mean reduction effect $(75.3 \%)$ followed by CAPL2 oil $^{\Theta}(74.5 \%)$ without significant differences in between, and so followed by Super Masrona oil ${ }^{\circledR}$ and Tiger oil ${ }^{\circledR}$ with significant differences by mean reduction effect $(72.5 \%)$ and $(72.6 \%)$ respectively. Admire insecticide caused mean reduction effect value $(68.5 \%)$ without significant differences with $\mathrm{Kz}$ oil ${ }^{\Theta}$ which caused mean reduction effect as $(67.3 \%)$.

Generally, it could be recommended that, light summer oils gave successful control against armored red-scale insect infesting orange trees in Beheira governorate, where they were more effective and less environmental hazards than the other chemical groups. The obtained results are in agreement with Helmy et al. (1992), Moursi (1996), El-Deeb (1999), Abdel-Rhaman et al., (2002) El-Deeb et al.,(2002), Mona et al.,(2002)and Abo-Shanab (2005).

\section{REFERENCES}

Abdel-Rhaman, S.M.; A.S.H. Abo-Shanab and S.A. Badr. 2002. Efficiency of some local mineral oils, insecticides and their binary mixtures on two coccoid species and predatory mites of guava trees in Alexandria district. J. Pest Cont. \& Environ. Sci., 10 (1): 13-26.

Abo-Shanab, A.S. 2005. Efficacy of some IGR/insecticides, Kz mineral oil and binary mixtures on mortality and enzyme activity of Egyptian mealy bug Iceria aegyptiaca(Douglas) attacked Guava trees in Alexandria Governorate. J. Pest Cont. \& Environ. Sci., 13(1): 73-85.

Chapman, P.J; L.A. Riehl and G.W. Pearce. 1952. Oil sprays for fruit trees in: Insects:"The Year book of Agriculture" Ed., A. Stefferud, U.S.A. Washington, D.C. pp.780.

Darwish, E.T.E. 1970. Biological and control studies on the scale insects attacking citrus trees in Menofia province. M. Sc. Thesis, Fac. of Agric., Tanta Univ., Egypt, 183 PP

El-Deeb, M.F. 1999. Evaluation of some local spray oils and bio-insecticides for the control of citrus white flies and mealybug on citrus trees. J. Pest Cont. \& Environ. Sci., 7 (3): 15-24.

El-Deeb, M.F., A.S.H. Abo-Shanab, S.M. Beshr and K.S. Moursi. 2002. Different types of pesticides and their mixtures for controlling the olive tree scale insect, Leucaspis riccae Targ. on olive trees by fogging and spraying 
machine at Burg El-Arab area. 2nd Int. Conf. of Plant Protection Research Institute, Cairo, Egypt, 21-24 December 2002, 882- 885.

El-Sebae, A.H., F.A. Hossam El-Deen, M. Abo El-Amayem and A. Marei. 1976. Studies on the chemical structure and insecticidal activity of local spray oils. $2^{\text {nd }}$ Arab. Conf. Petrochem., Abo Dhabi (5):4.

Farag, A.I.,M.M.Abdel Rahim,E.T.E. Darwish and A.M. Zaki. 1989. On the abundance of certain insect and mite pests on different citrus varieties. Proc. Ist. Ent. Conf. Ec. Ent. Vol (1): 313-324.

Florida Citrus Pest Management Guide. 2007. Entomology and Nematology Department, Florida Cooperative Extension Service, Institute of Food and Agricultural Sciences, University of Florida, EDIS Web site: http://edis.ifas.ufl.edu.

Habib, A., H.S. Salama and A.H. Amin. 1971. Population studies on scale insects infesting citrus in Egypt. Z. Angew. Ent., 69: 318-330.

Helmy, E.L., F.A. Youssef, W. El-Deeb and F.A. Ibrahim. 1992. Effect of certain minerals oils on the citrus purple scale insect Lepidosaphes becxii (McWm.) and their influence on plant structure, Egypt. J. Agric. Res., 70 (3): $817-825$.

Henderson, C.F. and E.W. Tilton. 1955. Tests with acaricides against the brown wheat mite. J. Econ. Entomol., 48: 157-161.

Kennett, C.E.; J.A. McMurtry and J.W. Beardsley. 1999. Biological control in subtropical and tropical crops. In: Bellows, T.S. and T.W. Fisher (eds.), Handbook of Biological Control : Principles and Applications. Academic Press, San Diego, New York. $1046 \mathrm{p}$

Micks, D.W. and J.A. Berlin. 1970. Continued susceptibility of Culex pipiens to petroleum hydrocarbons. J. Econ. Entomol., 63: 1996.

Mona H. Tawfik, A.A. Mohamed and H.M. Gamal. 2002. The Effect Of Summer Spray Materials On Red Scale Insect, Aondiella Aurantii, (Homoptera :Diaspididae), Side Effect on Host Plant and Associated Parasitoid. 2nd International Conference, Plant Protection Research Institute, Cairo, Egypt, 21-24 December, 2002, (1): 866-869.

Moursi, K.S. 1996. Integrated Pest Management of Olive, Almond, Fig and Guava in Northern Western Coast of Egypt. Report $4^{\text {th }}$ (Project No. 6 funded by Regional Council for Agricultural research and Extension). P 80.

Snedecor, G.W. 1961. Statistical methods. lowa State College, Ames, USA 534pp. 


\section{الملخص العربى \\ دراسة كفاءة بعض المبيدات الحشرية على حشرة الموالح الحمراء التى تصيب

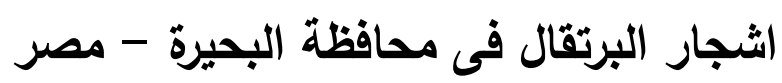

\section{رشا سعيد عبد الفتاح}

معهُ بحوث وقاية النباتات - مركز البحوث الزراعية

تم تتفيذ تجربتين لاختبار كفاءة بعض المبيدات الحشرية فى مكافحة حشرة الموالح الحمراء (حشرة قشرية

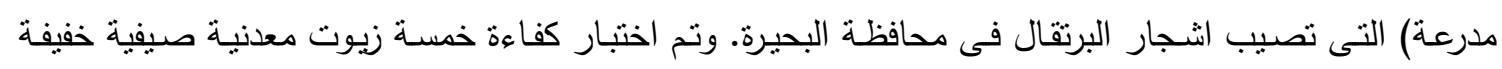
مختلفة فى نسبة النقاوة [سوبر مصرونا 95\%، زيت دايفر 97\%، زئ زيت تيجر

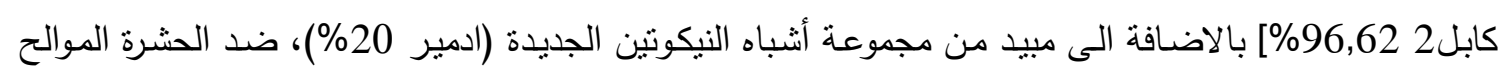

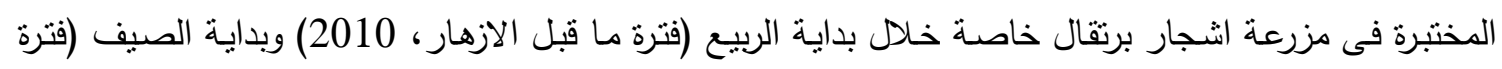

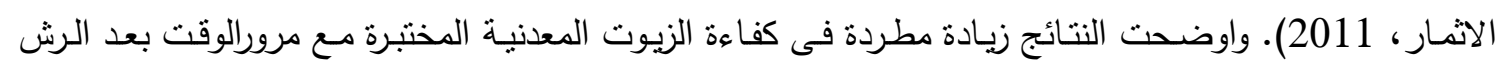

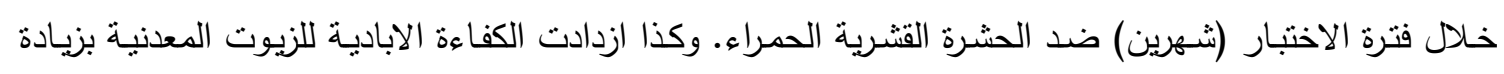

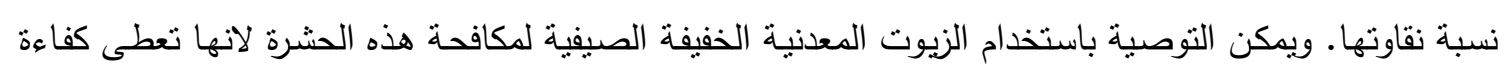

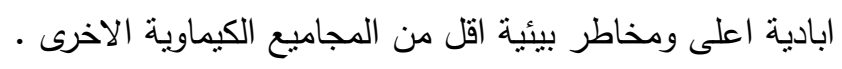


